\title{
Induction of Systemic Resistance against Insect Herbivores in Plants by Beneficial Soil Microbes
}

\author{
Md. Harun-Or-Rashid and Young R. Chung * \\ Division of Applied Life Science (BK21 Plus), Plant Molecular Biology and Biotechnology Research Center, Gyeongsang \\ National University, Jinju, South Korea
}

OPEN ACCESS

Edited by:

Monica Höfte,

Ghent University, Belgium

Reviewed by:

Munusamy Madhaiyan,

Temasek Life Sciences Laboratory,

Singapore

Simon Zebelo,

University of Maryland Eastern Shore,

United States

${ }^{*}$ Correspondence:

Young R. Chung

yrchung@gnu.ac.kr

Specialty section:

This article was submitted to

Plant Microbe Interactions,

a section of the journal

Frontiers in Plant Science

Received: 21 April 2017

Accepted: 06 October 2017

Published: 20 October 2017

Citation:

Rashid MH and Chung YR (2017)

Induction of Systemic Resistance against Insect Herbivores in Plants by

Beneficial Soil Microbes.

Front. Plant Sci. 8:1816.

doi: 10.3389/fpls.2017.01816
Soil microorganisms with growth-promoting activities in plants, including rhizobacteria and rhizofungi, can improve plant health in a variety of different ways. These beneficial microbes may confer broad-spectrum resistance to insect herbivores. Here, we provide evidence that beneficial microbes modulate plant defenses against insect herbivores. Beneficial soil microorganisms can regulate hormone signaling including the jasmonic acid, ethylene and salicylic acid pathways, thereby leading to gene expression, biosynthesis of secondary metabolites, plant defensive proteins and different enzymes and volatile compounds, that may induce defenses against leaf-chewing as well as phloem-feeding insects. In this review, we discuss how beneficial microbes trigger induced systemic resistance against insects by promoting plant growth and highlight changes in plant molecular mechanisms and biochemical profiles.

Keywords: beneficial soil microbes, induced systemic resistance, insect herbivores, priming, signaling pathway

\section{INTRODUCTION}

Plants are primary producers of organic nutrients, which nurture all heterotrophic organisms in the natural ecosystem. Especially in soils, plants play crucial roles in a complex food web system where many microorganisms utilize the plant's supplied nutrients in exchange for a limiting resource (Paul, 2007). In the interactions between soil microorganisms and host plants, the root system is the predominant host, which deposits up to $40 \%$ of photosynthetic carbon into the root zone. The rhizosphere is the greatest energy-rich zone in the ecosystem (Bais et al., 2006). The beneficial rhizosphere microbiota includes PGPR and PGPF. These genera enhance plant growth and improve health in many different ways (Lugtenberg and Kamilova, 2009; Shoresh et al., 2010). A wide range of beneficial microbes also provide plants with important capabilities, such as enriched nutrient uptake, growth promotion, and defense from pathogens and insects (Lugtenberg and Kamilova, 2009; van de Mortel et al., 2012; Lareen et al., 2016).

Beneficial microorganisms in plant roots can improve plant health by priming the entire plant to increase the defense against various pathogens and insect herbivores by the mechanism of ISR (Pieterse et al., 2014). ISR is activated by non-pathogenic bacteria in SA-independent and -dependent manners, and somewhat intersects with the JA/ET pathway. SAR is stimulated by

Abbreviations: ABA, abscisic acid; CK, cytokinin; ET, ethylene; GA, gibberellin; HIPVs, herbivore induced plant volatiles; IAA, indole-3-acetic acid; ISR, induced systemic resistance; JA, jasmonic acid; LOX2, lipoxygenase 2; MAMPs, microbe associated molecular patterns; NPR1, non-expressor of pathogenesis-related genes1; PDF1.2, plant defensin 1.2; PGPF, plant growth-promoting fungi; PGPR, plant growth-promoting rhizobacteria; POD, peroxidase; PPO, polyphenol oxidase; SA, salicylic acid; SAR, systemic acquired resistance; VOCs, volatile organic compounds. 
necrotizing pathogens and a SA-dependent signaling pathway, and results in enhanced level of SA and activation of PR proteins (Conrath et al., 2002; Hammerschmidt, 2009; Van der Ent et al., 2009). Pseudomonas fluorescens SS101 induces resistance against some plant pathogens such as $P$. syringae pv. tomato and the herbivorous insect pest Spodoptera exigua (van de Mortel et al., 2012). Hormone pathways and molecules participating in the recruitment of particular groups of microorganisms following foliar herbivore attack and defense stimulation have been reported (de Roman et al., 2011; Doornbos et al., 2011; Yang et al., 2011; Yi et al., 2011; Lakshmanan et al., 2012).

Jasmonic acid and SA are plant hormones that are central in coordinating the complex signaling pathways. Other hormones, such as auxin, ET, CK, ABA and GA, can also modulate signaling pathways during interactions between plants and biotic factors, pathogens and insects (Robert-Seilaniantz et al., 2011; Meldau et al., 2012; Pieterse et al., 2012; Giron et al., 2013). Therefore, plant-microbe and plant-insect interactions are connected through molecular pathways. Induction of hormone signaling pathways depends on insect feeding behaviors (Pineda et al., 2010). The phytohormones ET, JA, and SA can regulate symbiosis and mediate ISR triggered by beneficial microbes in the interactions occurring between non-pathogenic rhizosphere microbes and plants (De Vleesschauwer and Höfte, 2009; Zamioudis and Pieterse, 2012). Likewise, several rhizobacteria induce biochemical changes that trigger ISR in plants against insect herbivores (van de Mortel et al., 2012; Wielkopolan and Obrępalska-Stęplowska, 2016; Zebelo et al., 2016). However, little is known of the tri-trophic level interaction between plants, insects, and microbes (Pineda et al., 2010).

The present review focuses on the molecular mechanisms and biochemical profiles involved in the ISR elicited by beneficial microbes against insect herbivores and highlights recent findings that will help stimulate research on the tri-trophic level interaction.

\section{EFFECT OF PLANT HEALTH IMPROVEMENT BY SOIL MICROBES ON INTERACTION WITH INSECTS}

Beneficial soil microorganisms, such as PGPR and PGPF, can improve plant health by fixing atmospheric nitrogen, solubilizing plant foods otherwise unobtainable in special types of soils like rock phosphate and increasing the uptake of nutrients (Spaink, 2000; Harrison, 2005). Several microbes have the capacity to biosynthesize plant hormones including IAA, cytokinins, auxins and gibberellins, which are essential for promoting growth (Van Loon, 2007; Contreras-Cornejo et al., 2009). Some rhizobacteria can enhance plant growth via the biosynthesis of secondary metabolites, volatile compounds and enzymes and also increase plant photosynthesis by modulating endogenous sugar and ABA signaling (Zhang et al., 2008; Vacheron et al., 2013). Along with their plant growth-promoting properties, rhizobacteria can increase plant health and trigger resistance to plant pathogens and insect herbivores by inducing systemic defense responses (Van Wees et al., 2008; Segarra et al., 2009; Hossain et al.,
2016). These effects of soil microbes on improved plant growth affect plant-insect interactions, resulting in an enhanced food supply for insects. Furthermore, improved nutrient composition can increase nutritional value of plants, which affects insect performance at certain trophic levels (Schoonhoven et al., 2005; Bukovinszky et al., 2008). Different insects can benefit from the greater availability of nutrients in plant cells (Schoonhoven et al., 2005). Beneficial microbes enable the re-growth of tissues after herbivory due to increased nutrient and water uptake, which stimulates plant tolerance. This is reflected in detriments to plant yield or plant biomass in the presence of insects (Kula et al., 2005; Herman et al., 2008; Kempel et al., 2009). Moreover, greater photosynthesis efficiency enables beneficial microbes to convert more light energy, which allows the generation of an ISR against phloem feeder insects, which can compensate for the loss of plant energy (Valenzuela-Soto et al., 2010). Thus, microbes can improve plant health in various ways that include the increased uptake of nutrients, and the production of secondary metabolites, enzymes, volatile organic compounds, and growth hormones. All these directly or indirectly trigger ISR in plants against insect herbivores (Figure 1). However, these significant features have not been considered accurate enough to elucidate mechanisms of plant-microbe- insect interactions.

\section{ROLE OF PHYTOHORMONES IN ISR AGAINST INSECT HERBIVORES MEDIATED BY BENEFICIAL MICROBES}

Salicylic acid, ET, and JA are key plant hormones that regulate ISR during tri-trophic interactions (Shavit et al., 2013). These hormone-dependent pathways can regulate defense responses in different ways against specific types of attacking insects (Van Oosten et al., 2008). JA-mediated defenses are activated against herbivorous insects (Kessler et al., 2004; De Vos et al., 2005; Zheng et al., 2007; Howe and Jander, 2008; Van Oosten et al., 2008). JA signaling is the main ISR pathway activated to defend plants against leaf chewing insect pests, and is triggered by root-associated microorganisms (Van Oosten et al., 2008; Pineda et al., 2010; Jung et al., 2012). Arabidopsis roots treated with rhizobacteria induce resistance to chewing insects through the increased expression of JA-dependent gene LOX2 and the JA- and ET-dependent genes, PDF1.2 and HEL (Pangesti et al., 2015a). The colonization of plant roots by rhizobacterium P. simiae WCS417r elicits higher expression of the JA/ETdependent ORA59-branch than the JA-dependent MYC2 branch, and triggers ISR against leaf-chewing insects (Pangesti et al., 2016). Root colonization of cotton plants by PGPR induces higher levels of JA, an octadecanoid-derived, defense-related phytohormone and JA-related genes, which may confer resistance against the leaf-chewing insect, S. exigua (Zebelo et al., 2016).

Using different mechanisms, Bacillus subtilis PGPR induces resistance against the phloem insect whitefly on tomato plants (Solanum lycopersicum), increased expression of both JAindependent genes (including photosynthetic genes, phenylpropanoid and terpenoid biosynthetic pathways genes) and JAdependent genes including proteases and proteinase inhibitor 


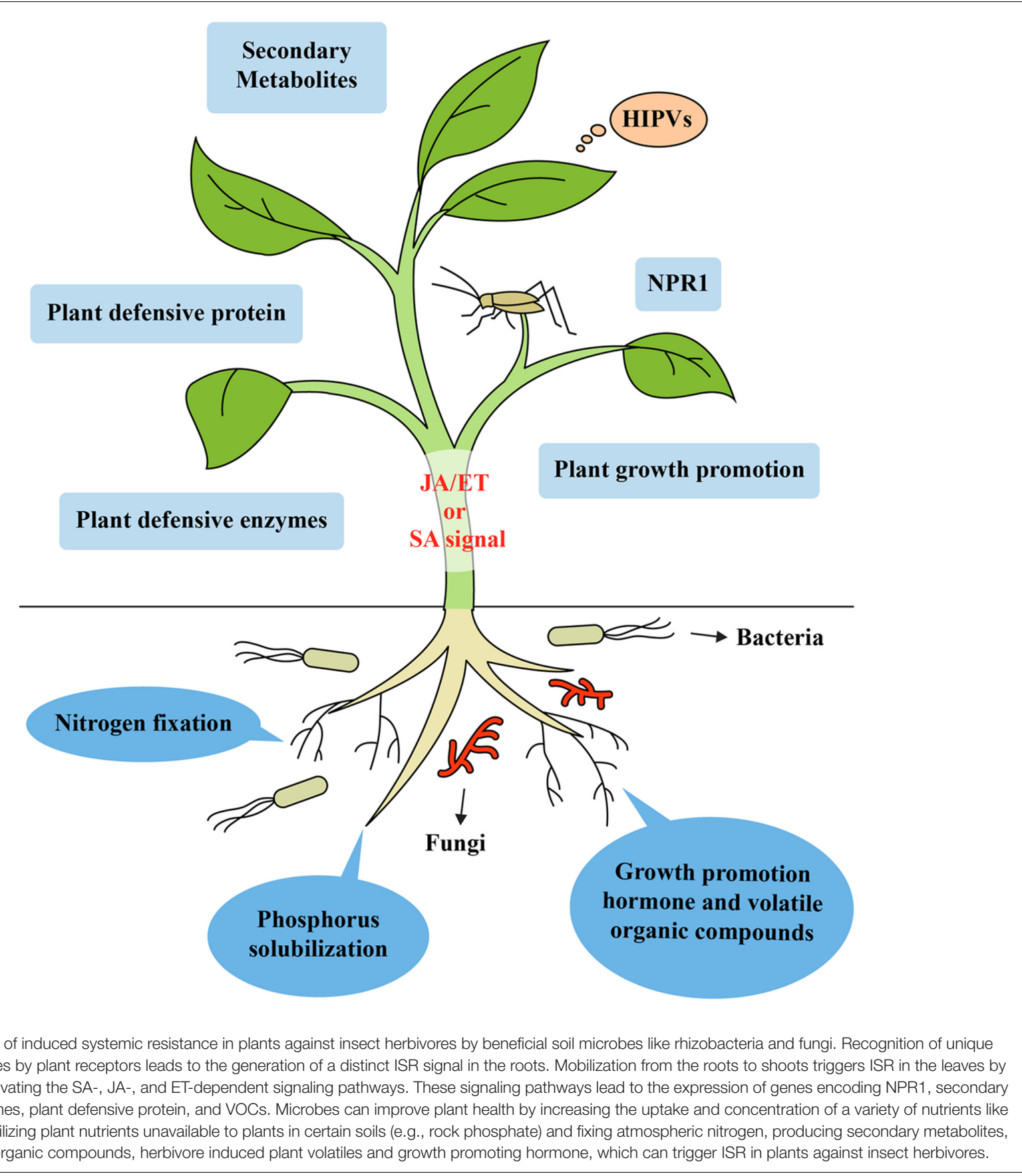

coding genes (Valenzuela-Soto et al., 2010). Pineda et al. (2012) reported that Arabidopsis roots colonized by $P$. fluorescens WCS417 $\mathrm{r}$ have enhanced susceptibility to the phloem-feeding aphid Myzus persicae, although treated plants showed stronger expression of LOX2 and PDF1.2 gene following insect attack. These studies show that different rhizobacteria genera including Bacillus and Pseudomonas have different effects against phloemfeeding insects. Further studies are needed.

Pseudomonas fluorescens SS101 activates ISR through SAdependent mechanisms, although most rhizobacteria facilitate ISR through JA- and ET-dependent mechanisms (van de Mortel et al., 2012). Niu et al. (2011) also showed that PGPR-triggered ISR is dependent on both the JA/ET- and SA- signaling pathways. It is assumed that the MAMPs of different beneficial microbes might be recognized by plant receptors leading to specific hormonal signals produced in the roots. MAMPs of beneficial microbes including flagellin, secondary metabolites and lipopolysaccharides activate MAMP-triggered immunity (MTI) and modulate hormonal signals in plants (Jacobs et al., 2011; Hermosa et al., 2012; Zamioudis and Pieterse, 2012). For example, B. amyloliquefaciens $S 499$ produces lipopeptides, which lead to enhanced expression of defense-related genes lipoxygenase 
$D$ and $F(L O X D, L O X F)$ that induced ISR in tomato plants (Cawoy et al., 2014). Another lipopeptide producing endophyte, B. amyloliquefaciens strain Blu-v2, elicits ISR in plants against fall armyworms (Li et al., 2015). The expression of ISR against pathogens and insects requires responsiveness to the SA- and JA/ET-signaling pathways and is dependent on 'non-expressor of pathogenesis-related genes1' (Pieterse et al., 1998; Mewis et al., 2005; Segarra et al., 2009; van de Mortel et al., 2012). Mobilization of distinct signal from the roots to the shoots triggers ISR in the leaves by simultaneously activating SA-, JA-, and ET-dependent signaling pathways. These signaling pathways may lead to the expression of genes encoding NPR1, which can trigger ISR against insect herbivores (Figure 1). Unfortunately, how the MAMPs of beneficial microbes modify phytohormone signaling pathways in the plants during interaction with insects is not completely understood. Further studies are required to clarify how microbial MAMPs affect plant hormonal signals by infestation of insect herbivores.

\section{INDUCED PRODUCTION OF DEFENSE-RELATED COMPOUNDS IN PLANT-MICROBE-INSECT INTERACTIONS}

Root colonization by beneficial microbes can induce biosynthesis of plant defense-related compounds against insects through various plant hormonal signaling pathways (van de Mortel et al., 2012; Pangesti et al., 2016). The production of defenserelated chemical compounds, such as flavonoids, lignin and other secondary metabolites, that produce effective defense against a wide range of plant pathogens and insect herbivores is regulated in the JA/ET and SA pathways (Pauwels et al., 2009; ValenzuelaSoto et al., 2010; Campos et al., 2014; Mejía et al., 2014). Among these compounds, camalexin and glucosinolates have important roles in plant defenses against pathogenic microbes, leaf chewers and sap sucking insect herbivores (Mewis et al., 2006; Kim et al., 2008; Kusnierczyk et al., 2008; Clay et al., 2009; Müller et al., 2010). The biosynthesis of camalexin and glucosinolates, which triggers ISR against leaf-chewing insects, is increased by rhizobacterial colonization of the roots via the JA and ET pathways (Pangesti et al., 2016). The colonization of Arabidopsis roots by P. fluorescens SS1011 can also induce the biosynthesis of these two compounds that enhance ISR against the lepidopteron insect pest, S. exigua, through an SA signaling pathway (van de Mortel et al., 2012). Thus, colonization of roots by different rhizobacterial species could induce the production of the same defense compounds, such as camalexin and glucosinolates, via different signaling pathways.

Flavonoids are well-known plant secondary metabolites that frequently act as insect feeding inhibitors and pigments, to promote pollination by attracting insects (Schoonhoven et al., 2005). These compounds are also found in root exudates and are essential in root colonization of rhizobacteria (Ferguson and Mathesius, 2003; Steinkellner et al., 2007; Dennis et al., 2010;
Zamioudis and Pieterse, 2012). Herbivory of the cabbage butterfly (Pieris rapae) and caterpillar (Helicoverpa armigera) can activate a group of JA-signaling pathways controlled by the transcription factor MYC2 that positively regulate the biosynthesis of flavonoids and anthocyanin, which produces resistance to the insect pests (De Vos et al., 2005; Dombrecht et al., 2007; Verhage et al., 2011). Fertilization of a microorganism-based product containing Bacillus and actinomycetes increases the expression of transcription factors such as TT8, EGL3, MYB12, $M Y B 114$ and MYB113, which activate the genes for flavonoid biosynthesis resulting in the accumulation of flavonoids in Arabidopsis plants (Ali and McNear, 2014). The flavonoid tricin that is extracted from bluegrass infected with the endophytic fungus, Neotyphodium typhnium, has insecticidal activity against mosquito larvae (Ju et al., 1998). Tricin also reportedly inhibits infestation of brown planthopper in a resistant rice cultivar (Bing et al., 2007). Recent studies have implicated tricin in biosynthesis of lignin in monocots (Lan et al., 2015; Li et al., 2016).

Among the other secondary metabolites, the most common group of defensive compounds are phenolic compounds. They are important in the resistance strategy against pathogenic microbes and herbivorous insects (Sharma et al., 2009; Rani and Jyothsna, 2010; Mazid et al., 2011; War et al., 2011). Phenolic compounds are accumulated by PGPR. They are directly toxic and/or produce a hypersensitive response (HR) in plants (Singh et al., 2015; Kiprovski et al., 2016). Colonization of rice roots by $P$. fluorescens WCS374r induces ISR, which enhances accumulation of phenolic compounds (De Vleesschauwer et al., 2008). Lignin is an important phenolic. It is a complex phenolic heteropolymer that confers resistance against attack by herbivorous insects (Barakat et al., 2010). Increased lignin content in the plant cell wall can physically limit the entrance and feeding of insect herbivores by increasing leaf hardiness (Johnson et al., 2009). The biosynthesis of lignin and different oxidative phenols that participate in plant defense against insect pests is catalyzed by PPO and POD (Bhonwong et al., 2009; Gulsen et al., 2010). P. fluorescens strains Pf1, TDK1 and PY15 display ISR against the leaffolder larvae (Cnaphalocrocis medinalis) by the activation of PPO in rice plants (Saravanakumar et al., 2008). Treatment of Arabidopsis with beneficial microorganisms induces the expression of lignin pathway genes and results in the increased lignin content in leaves (Ali and McNear, 2014). Endophytic colonization by a foliar fungus increases the lignin content of leaves, which reduces the damage caused by pathogens and herbivore attack (Mejía et al., 2014). The mechanism of induced resistance against insects by beneficial soil microbes related with lignin biosynthesis remains unclear.

Gossypol is a phenolic sesquiterpenoid aldehyde that confers resistance to infestation by many chewing and sucking insect pests belonging to Aphididae, Miridae, Tetranychidae, Thripidae, and caterpillars. Especially, the host infestation capability of Heliothis and Helicoverpa (Noctuidae) larvae is suppressed by antibiosis or by aversion to cotton because of the high amount of gossypol in these plants (Syed et al., 2003; Du et al., 2004; Stipanovic et al., 2006). Exogenous application 
of JA to cotton plants can increase the level of gossypol, which reduces the growth and development of the mealybug, Phenacoccus solenopsis (Zhang et al., 2011). Treatment with Bacillus spp. can induce the expression of JA-related genes GhLOX1, GhAOS and GhOPR3, which initiates transcription of gossypol biosynthesis genes including the $(+)-\delta$ - cadinene synthase (CAD1) gene family ( $C d n 1-A, C A D 1-C 1, C d n 1$ $C 3$, and $C d n 1-C 14)$ to reduce herbivory by $S$. exigua larvae. The induced resistance of cotton plants against $S$. exigua might be due to the enhanced level of gossypol (Wu et al., 2010; Zebelo et al., 2016). Unlike other secondary metabolites, proteins like lipoxygenase (LOX) and jacalin-related lectin are associated with numerous defense related processes, which include formation of cell wall structure, stress adaptation and resistance to pathogens and insects in several crops (Pauwels et al., 2009; Tong et al., 2012). LOX has a prominent and direct role in stimulating plant defense by producing protease inhibitors and oxidative enzymes (Mao et al., 2007). P. fluorescens triggers ISR against the leaffolder larvae in rice plants by the activation of several enzymes including LOX, chitinases and trypsin inhibitors (Commare et al., 2002; Saravanakumar et al., 2007, 2008). The jacalin-related lectin Orysata reportedly displays insecticidal activity that protects plants against different types of insects (Al Atalah et al., 2014). The lectin is induced in soybean plants during interaction with bacterial pathogens including Xanthomonas axonopodis pv. glycines, P. syringae pv. Tomato, and B. amyloliquefaciens KPS46 (Buensanteai et al., 2009). However, the mechanism of induced production of this plant defensive protein following insect infestation by beneficial microbes is unknown. On the basis of recent advances in defense-related chemicals with ISR against insect herbivores, we suggest that plant defenses against insect herbivores can be induced by beneficial soil microbes through biochemical and physiological changes in plant cells. For example, the induced production of a chemical, such as the flavonoid tricin, is not only a chemical inhibitor of insects. Rather, it may be linked to physical modifications of cell wall by lignification. Beneficial soil microbes may induce reactions that lead to the production of both chemical and physical barriers to the infestation of plants by insect herbivores. We are only at the early stage of understanding how beneficial soil microbes modulate and regulate plant defenses against insect herbivores through metabolic changes. Further knowledge will require studies of the molecular mechanisms in tri-trophic levels. This understanding will inform the development of strategies for efficient biological pest management.

\section{BACTERIAL VOLATILE ORGANIC COMPOUNDS AND HERBIVORE-INDUCED PLANT VOLATILES IN PLANT DEFENSE}

Ryu et al. (2004) first showed that VOCs including 2, 3butanediol and acetoin produced by PGPR Bacillus species initiate ISR that is dependent on ET and independent of the JA or SA signaling pathways in Arabidopsis. VOCs are also produced upon infestation of plants by insects. These are termed HIPVs. HIPVs can protect plants directly by deterring, repelling or poisoning the herbivores, and may act indirectly by enticing natural enemies of the attackers (Maffei, 2010; Aartsma et al., 2017; Martorana et al., 2017). Production of HIPVs is facilitated primarily by an interplay of the JA, SA, and ET pathways (Koornneef and Pieterse, 2008; Van der Ent et al., 2009; Jung et al., 2012). Infestation of several leaf chewing insects initiates the expression of terpene genes that are dependent on JA signaling, and which might play a role in insect-plant interactions (Dombrecht et al., 2007; Dicke and Baldwin, 2010; Verhage et al., 2011; Hong et al., 2012). Rhizobacterial treatment might enhance the biosynthesis of HIPVs. Colonization of Arabidopsis roots by $P$. fluorescens WCS417r increases the transcription of JAdependent genes to produce plant volatiles upon caterpillar attack (Pangesti et al., 2015a). In addition, treatment with this bacterium can repress the release of aromatics including methyl salicylate, lilial, and terpene $(E)-\alpha$ - bergamotene by decreasing the expression of the terpene synthase genes TPSO3 and TPSO4 upon caterpillar attack. This results in the attraction of more parasitoids of the caterpillar to the caterpillar-attacked plants, which produces an indirect plant defense against the attacking herbivores (Pangesti et al., 2015b). This highlights the important role of VOCs in both direct and indirect plant resistance strategies against insect herbivores (Schausberger et al., 2012; Kamolsukyunyong et al., 2013). The collective knowledge supports the view that enhanced production of VOCs and HIPVs in association with beneficial soil microbes should be further developed to yield innovative tactics to control insect herbivores in an effective and environmentally friendly way.

\section{HYPERSENSITIVE RESPONSE IN ISR AGAINST INSECT HERBIVORES}

Microbe-mediated ISR that occurs upon insect infestation and pathogen infection includes HR-type reactions, elevated cell wall or apoplastic peroxidase activity, callose deposition and hydrogen peroxide $\left(\mathrm{H}_{2} \mathrm{O}_{2}\right)$ accumulation (Conrath, 2006; Valenzuela-Soto et al., 2010; Niu et al., 2011; Rahman et al., 2015). Insect feeding induces oxidative stress responses that are essential elements of plant defense against the attacking insects. Likely, the biosynthesis of reactive oxygen species (ROS) and consequent cell death leads to systemic resistance in pathogen-infected plants (Jones and Dangl, 2006; Mur et al., 2007). ROS detoxification might reduce antioxidant levels, but increases poisonous oxidation elements in soybeans infested with corn earworm (Bi and Felton, 1995). ROS and local cell death are important measures employed by plants to protect themselves against the phloem sap feeding green peach aphid (Lei et al., 2014). Increased levels of $\mathrm{H}_{2} \mathrm{O}_{2}$ and other ROS in plants can directly kill insects by causing intestinal destruction. The mortality of green peach aphid following consumption of artificial diets containing $\mathrm{H}_{2} \mathrm{O}_{2}$ also 
supports the hypothesized effects of ROS (Liu et al., 2010). Accumulation of $\mathrm{H}_{2} \mathrm{O}_{2}$ enhances the protection against the phloem sap sucking brown planthopper (Nilaparvata lugens) in rice (Zhou et al., 2009). Programmed cell death (PCD) is a major plant defense factor against insect herbivores including aphids. PCD manipulates the nutritional quality of the host in plant-microbe interactions (Goggin, 2007; Mur et al., 2007). Rhizobacterial stimulation of LOX activates the oxylipin pathway to change fatty acids into reactive hydroperoxides, which can be further modified into diverse defense metabolites (Shah, 2005; Cawoy et al., 2014). Exposure of Arabidopsis roots with the endophytic bacterium, B. velezensis YC7010, can induce systemic resistance to aphids due to the increased accumulation of $\mathrm{H}_{2} \mathrm{O}_{2}$, cell death and deposition of callose in leaves (Rashid et al., 2017). The collective data indicate that ROS accumulation in plants interacting with microbes is an early defense response against insect predation. However, higher accumulation of ROS in plants may have detrimental effects (Walz et al., 2002). Du et al. (2015) showed that ROS scavengers, such as peroxidases, can obviate the detrimental effects and can induce defense against the brown planthopper in resistant rice cultivars. It is conceivable that alterations in redox status resulting from higher levels of ROS scavengers in plants courtesy of beneficial microbes might contribute to ISR upon insect infestation. Additional HR studies in terms of redox status to elucidate the mechanism of plant defense in the interaction between microbes, plants, and insects.

\section{MODULATION OF HOST IMMUNITY AND PRIMED ENHANCED ISR AGAINST INSECT HERBIVORES BY BENEFICIAL SOIL MICROBES}

The immune system of plants features specified patternrecognition receptors (PRRs) that identify common microbial compounds, such as fungal chitin or bacterial flagellin. The patterns are termed MAMPs and PAMPs. Recognition of PAMPs or MAMPs by receptors is the first step in the basal plant defense response, which is collectively termed MTI (Jones and Dangl, 2006; Boller and Felix, 2009; Monaghan and Zipfel, 2012). Colonization of the root system of host plants with beneficial microbes is required to initiate ISR (Lugtenberg and Kamilova, 2009). Microorganisms that interact with a host plant need to avoid MTI responses if they are to effectively colonize the host (Zamioudis and Pieterse, 2012). P. fluorescens WCS417r can suppress flagellin-triggered MTI responses and can induce callose deposition during colonization of Arabidopsis (Millet et al., 2010). Callose deposition is also a central protection strategy that inhibits insects from ingesting phloem fluid (Hao et al., 2008). MAMPS and effector molecules are commonly used by ISR-inducing microbes to suppress host immunity (Zamioudis and Pieterse, 2012). For example, ISR-inducing fungus Rhizophagus intraradices can suppress ET- dependent defense responses utilizing the symbiotic effector SP7, thus promoting fungal biotrophy (Kloppholz et al., 2011). The

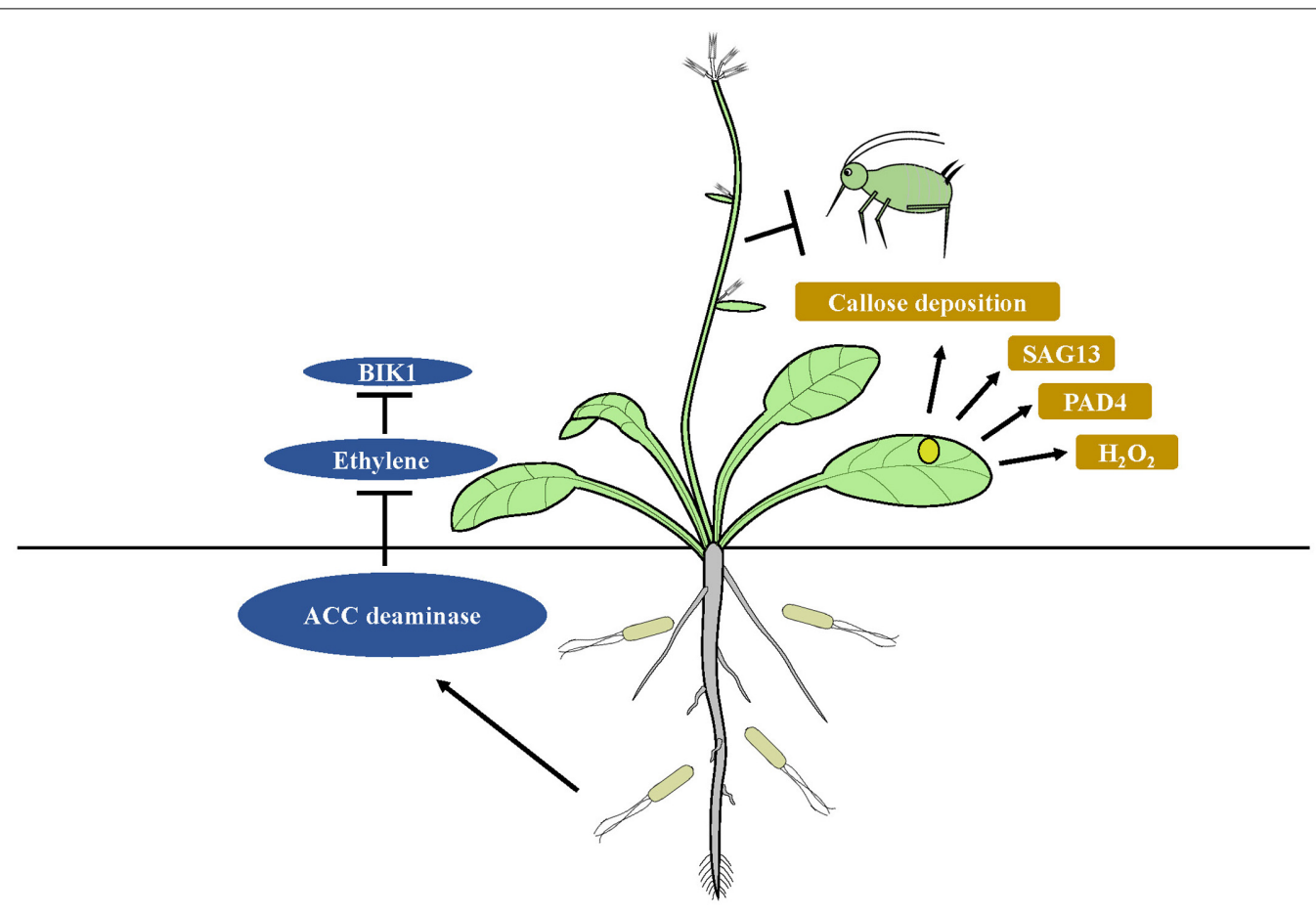

FIGURE 2 | Model of suppression of host immunity by ISR-inducing microbes. Degradation of the ethylene precursor ACC by bacterial ACC deaminase, which suppresses ET-mediated immune responses like BIK1, results in higher expression levels of PAD4 and SAG13 in microbe treated plants. Enhanced expression of PAD4 triggers more rapid $\mathrm{H}_{2} \mathrm{O}_{2}$ accumulation, cell death and callose deposition in plants, which can trigger ISR in the plants against insect herbivores. 
1-aminocyclopropane-1-carboxylate (ACC) deaminase produced by rhizobacteria facilitates plant development and growth, as well as mycorrhizal colonization in various crops by decreasing ET levels (Nadeem et al., 2007; Shaharoona et al., 2008; Zahir et al., 2008). Inhibition of ET perception results from the blocked activity of BOTRYTIS-INDUCED KINASE1 (BIK1) localized at the plasma membrane, which acts early in defense response pathways (Veronese et al., 2006; Laluk et al., 2011). BIK1 modulates responses of plants to phloem sap-feeding insect infestation by regulating the expression of PAD4, which is much higher in bik1 mutants. The latter can induce resistance to phloem sap-feeding insects by production of ROS, cell death and leaf senescence. However, BIK1 overexpression can render Arabidopsis plants more susceptible to aphid infestation (Lei et al., 2014). PAD4 gene stimulates premature leaf senescence, which can confer resistance to aphids (Pegadaraju et al., 2005). ISR mediated by endophytic bacteria B. velezensis YC7010 against green peach aphid depends mainly on the elevated expression of PAD4 with suppression of BIK1 resulting in greater accumulation of $\mathrm{H}_{2} \mathrm{O}_{2}$, cell death and callose deposition in Arabidopsis (Rashid et al., 2017). It has been suggested that degradation of the ethylene precursor ACC by bacterial ACC deaminase, which suppresses ET-mediated immune responses like $B I K 1$, results in higher expression levels of PAD4 and SAG13 in Arabidopsis colonized by bacteria. Enhanced expression of PAD4 by the bacteria triggers more rapid $\mathrm{H}_{2} \mathrm{O}_{2}$ accumulation, cell death and callose deposition in plants, which can trigger ISR in the plants against insect herbivores (Figure 2). How beneficial rhizobacteria induce ISR against insects by suppression of plant immune responses remains unclear.

Beneficial soil microbes have coevolved with host plants for long time. Thus, they may have developed the means to overcome MTI for their mutualism to colonize host plants. Priming is a good strategy to save energy costs for even though these microbes suppress basal defense responses in the host roots (Verhagen et al., 2004; Pozo et al., 2008; Van Wees et al., 2008; Rashid et al., 2017). Primed plants display quicker and/or stronger initiation of cellular defenses when challenged by pathogen or insect attack to improve the level of defense (Conrath, 2011). ISR mediated by beneficial soil microorganisms is normally dependent on priming (Pieterse et al., 2014). Molecular changes that happen in systemic tissues upon colonization of the plant roots by beneficial microorganisms are generally minor compared to the huge molecular reprogramming triggered by pathogen or insect attack in primed plants (Pieterse et al., 2014). The primed state is frequently opaque in unchallenged plants by insects or pathogens. Priming occurs only after insect or pathogen challenge, but does not occur when the leaves are damaged by the ISR-insensitive specialist herbivore, Pieris rapae (Van Oosten et al., 2008). Priming mediated by the rhizobacterium $P$. putida LSW17S is based on JA, ET, and NPR1 in Arabidopsis plants (Ahn et al., 2007) Additionally, colonization of tomato plants by mycorrhiza can prime systemic defense responses against insect attack with increased expression of defense associated genes allene oxide cyclase (AOC), LOXD and protease inhibitors (PI-I, PI-II) (Song et al., 2013).

\section{CONCLUSION AND FUTURE PERSPECTIVES}

Interactions among beneficial microbes, plants, and insects mainly involve plant growth promotion and ISR. Unlike ISR against plant pathogens, which has been well-studied for several decades, little information is available about the ISR activity against insect herbivores in related with the microbes in soil. The activation of ISR by beneficial microbes against insects through recognition of the microbes, elicitation of specific hormonal signal pathways may play vital role in plant defense responses. The biosynthesis pathways for defense related chemical compounds, enzymes, protein, secondary metabolites, and VOCs against insect herbivores can be activated by root colonization by beneficial microbes. One of the plant defense responses against insects, the accumulation of ROS scavenger peroxidases allow biosynthesis of secondary metabolites and flavonoids (especially tricin) that participate in lignin biosynthesis. The metabolic change in the biosynthesis of chemicals as direct inhibitors or repellents of insects might be also involved in physical strengthening of cell wall by lignification. This review has provided up-to-date information on the chemical changes and strengthening of physical barriers, which play important roles comprehensively in plant defense system against insect herbivores. Selecting beneficial soil microorganisms might be a more effective and cheaper way to manage the insect herbivores than development of chemical pesticides. This approach would contribute to sustainable insect pests control by development of bioproducts that would enhance plant productivity and simultaneously induce systemic resistance against insects or attractiveness to beneficial insects.

\section{AUTHOR CONTRIBUTIONS}

$\mathrm{MR}$ and $\mathrm{YC}$ conceived the premise for this review.

\section{ACKNOWLEDGMENTS}

This study was carried out with the support of "Cooperative Research Program for Agriculture Science \& Technology Development (PJ01104901)" funded by Rural Development Administration, South Korea. MR was supported by a scholarship from the BK21 Plus Program, the Ministry of Education, South Korea. 


\section{REFERENCES}

Aartsma, Y., Bianchi, F. J., Werf, W., Poelman, E. H., and Dicke, M. (2017). Herbivore-induced plant volatiles and tritrophic interactions across spatial scales. New Phytol. doi: 10.1111/nph.14475 [Epub ahead of print].

Ahn, I. P., Lee, S. W., and Suh, S. C. (2007). Rhizobacteria-induced priming in Arabidopsis is dependent on ethylene, jasmonic acid, and NPR1. Mol. Plant Microbe Interact. 20, 759-768. doi: 10.1094/MPMI-20-7-0759

Al Atalah, B., Smagghe, G., and Van Damme, E. J. (2014). Orysata, a jacalinrelated lectin from rice, could protect plants against biting-chewing and piercing-sucking insects. Plant Sci. 221, 21-28. doi: 10.1016/j.plantsci.2014. 01.010

Ali, M. B., and McNear, D. H. (2014). Induced transcriptional profiling of phenylpropanoid pathway genes increased flavonoid and lignin content in Arabidopsis leaves in response to microbial products. BMC Plant Biol. 14:84. doi: 10.1186/1471-2229-14-84

Bais, H. P., Weir, T. L., Perry, L. G., Gilroy, S., and Vivanco, J. M. (2006). The role of root exudates in rhizosphere interactions with plants and other organisms. Annu. Rev. Plant Biol. 57, 233-266. doi: 10.1146/annurev.arplant.57.032905. 105159

Barakat, A., Bagniewska-Zadworna, A., Frost, C. J., and Carlson, J. E. (2010). Phylogeny and expression profiling of $C A D$ and $C A D$-like genes in hybrid Populus $(P$. deltoides $\times P$. nigra): evidence from herbivore damage for subfunctionalization and functional divergence. BMC Plant Biol. 10:100. doi: 10.1186/1471-2229-10-100

Bhonwong, A., Stout, M. J., Attajarusit, J., and Tantasawat, P. (2009). Defensive role of tomato polyphenol oxidases against cotton bollworm (Helicoverpa armigera) and beet armyworm (Spodoptera exigua). J. Chem. Ecol. 35, 28-38. doi: 10.1007/ s10886-008-9571-7

Bi, J. L., and Felton, G. W. (1995). Foliar oxidative stress and insect herbivory: primary compounds, secondary metabolites, and reactive oxygen species as components of induced resistance. J. Chem. Ecol. 21, 1511-1530. doi: 10.1007/ BF02035149

Bing, L., Hongxia, D., Maoxin, Z., Di, X., and Jingshu, W. (2007). Potential resistance of tricin in rice against brown planthopper Nilaparvata lugens (Stål). Acta Ecol. Sin. 27, 1300-1306. doi: 10.1016/S1872-2032(07) 60031-6

Boller, T., and Felix, G. (2009). A renaissance of elicitors: perception of microbeassociated molecular patterns and danger signals by pattern-recognition receptors. Annu. Rev. Plant Biol. 60, 379-406. doi: 10.1146/annurev.arplant.57. 032905.105346

Buensanteai, N., Yuen, G. Y., and Prathuangwong, S. (2009). Priming, signaling, and protein production associated with induced resistance by Bacillus amyloliquefaciens KPS46. World J. Microbiol. Biotechnol. 25, 1275-1286. doi: 10.1007/s11274-009-0014-6

Bukovinszky, T., van Veen, F. F., Jongema, Y., and Dicke, M. (2008). Direct and indirect effects of resource quality on food web structure. Science 319, 804-807. doi: $10.1126 /$ science. 1148310

Campos, M. L., Kang, J. H., and Howe, G. A. (2014). Jasmonate-triggered plant immunity. J. Chem. Ecol. 40, 657-675. doi: 10.1007/s10886-014-0468-3

Cawoy, H., Mariutto, M., Henry, G., Fisher, C., Vasilyeva, N., Thonart, P., et al. (2014). Plant defense stimulation by natural isolates of Bacillus depends on efficient surfactin production. Mol. Plant Microbe Interact. 27, 87-100. doi: 10.1094/MPMI-09-13-0262-R

Clay, N. K., Adio, A. M., Denoux, C., Jander, G., and Ausubel, F. M. (2009). Glucosinolate metabolites required for an Arabidopsis innate immune response. Science 323, 95-101. doi: 10.1126/science.1164627

Commare, R. R., Nandakumar, R., Kandan, A., Suresh, S., Bharathi, M., Raguchander, T., et al. (2002). Pseudomonas fluorescens based bio-formulation for the management of sheath blight disease and leaffolder insect in rice. Crop Prot. 21, 671-677. doi: 10.1016/S0261-2194(02)00020-0

Conrath, U. (2006). Systemic acquired resistance. Plant Signal. Behav. 1, 179-184. doi: $10.4161 /$ psb.1.4.3221

Conrath, U. (2011). Molecular aspects of defence priming. Trends Plant Sci. 16, 524-531. doi: 10.1016/j.tplants.2011.06.004

Conrath, U., Pieterse, C. M., and Mauch-Mani, B. (2002). Priming in plantpathogen interactions. Trends Plant Sci. 7, 210-216. doi: 10.1016/S13601385(02)02244-6
Contreras-Cornejo, H. A., Macías-Rodríguez, L., Cortés-Penagos, C., and López-Bucio, J. (2009). Trichoderma virens, a plant beneficial fungus, enhances biomass production and promotes lateral root growth through an auxin-dependent mechanism in Arabidopsis. Plant Physiol. 149, 1579-1592. doi: $10.1104 /$ pp.108.130369

de Roman, M., Fernandez, I., Wyatt, T., Sahrawy, M., Heil, M., and Pozo, M. J. (2011). Elicitation of foliar resistance mechanisms transiently impairs root association with arbuscular mycorrhizal fungi. J. Ecol. 99, 36-45. doi: 10.1111/j. 1365-2745.2010.01752.x

De Vleesschauwer, D., Djavaheri, M., Bakker, P. A., and Höfte, M. (2008). Pseudomonas fluorescens WCS374r-induced systemic resistance in rice against Magnaporthe oryzae is based on pseudobactin-mediated priming for a salicylic acid-repressible multifaceted defense response. Plant Physiol. 148, 1996-2012. doi: $10.1104 /$ pp.108.127878

De Vleesschauwer, D., and Höfte, M. (2009). Rhizobacteria-induced systemic resistance. Adv. Bot. Res. 51, 223-281. doi: 10.1016/S0065-2296(09)51006-3

De Vos, M., Van Oosten, V. R., Van Poecke, R. M., Van Pelt, J. A., Pozo, M. J., Mueller, M. J., et al. (2005). Signal signature and transcriptome changes of Arabidopsis during pathogen and insect attack. Mol. Plant Microbe Interact. 18, 923-937. doi: 10.1094/MPMI-18-0923

Dennis, P. G., Miller, A. J., and Hirsch, P. R. (2010). Are root exudates more important than other sources of rhizodeposits in structuring rhizosphere bacterial communities? FEMS Microbiol. Ecol. 72, 313-327. doi: 10.1111/j.15746941.2010.00860.x

Dicke, M., and Baldwin, I. T. (2010). The evolutionary context for herbivoreinduced plant volatiles: beyond the cry for help. Trends Plant Sci. 15, 167-175. doi: 10.1016/j.tplants.2009.12.002

Dombrecht, B., Xue, G. P., Sprague, S. J., Kirkegaard, J. A., Ross, J. J., Reid, J. B., et al. (2007). MYC2 differentially modulates diverse jasmonate-dependent functions in Arabidopsis. Plant Cell 19, 2225-2245. doi: 10.1105/tpc.106.048017

Doornbos, R. F., Geraats, B. P., Kuramae, E. E., Van Loon, L. C., and Bakker, P. A. (2011). Effects of jasmonic acid, ethylene, and salicylic acid signaling on the rhizosphere bacterial community of Arabidopsis thaliana. Mol. Plant Microbe Interact. 24, 395-407. doi: 10.1094/MPMI-05-10-0115

Du, B., Wei, Z., Wang, Z., Wang, X., Peng, X., Du, B., et al. (2015). Phloem-exudate proteome analysis of response to insect brown plant-hopper in rice. J. Plant Physiol. 183, 13-22. doi: 10.1016/j.jplph.2015.03.020

Du, L., Ge, F., Zhu, S., and Parajulee, M. N. (2004). Effect of cotton cultivar on development and reproduction of Aphis gossypii (Homoptera: Aphididae) and its predator Propylaea japonica (Coleoptera: Coccinellidae). J. Econ. Entomol. 97, 1278-1283. doi: 10.1093/jee/97.4.1278

Ferguson, B. J., and Mathesius, U. (2003). Signaling interactions during nodule development. J. Plant Growth Regul. 22, 47-72. doi: 10.1007/s00344-0030032-9

Giron, D., Frago, E., Glevarec, G., Pieterse, C. M., and Dicke, M. (2013). Cytokinins as key regulators in plant-microbe-insect interactions: connecting plant growth and defence. Funct. Ecol. 27, 599-609. doi: 10.1111/1365-2435.12042

Goggin, F. L. (2007). Plant-aphid interactions: molecular and ecological perspectives. Curr. Opin. Plant Biol. 10, 399-408. doi: 10.1016/j.pbi.2007. 06.004

Gulsen, O., Eickhoff, T., Heng-Moss, T., Shearman, R., Baxendale, F., Sarath, G., et al. (2010). Characterization of peroxidase changes in resistant and susceptible warm-season turfgrasses challenged by Blissus occiduus. Arthropod Plant Interact. 4, 45-55. doi: 10.1007/s11829-010-9086-3

Hammerschmidt, R. (2009). Systemic acquired resistance. Adv. Bot. Res. 51, 173-222. doi: 10.1016/S0065-2296(09)51005-1

Hao, P., Liu, C., Wang, Y., Chen, R., Tang, M., Du, B., et al. (2008). Herbivoreinduced callose deposition on the sieve plates of rice: an important mechanism for host resistance. Plant Physiol. 146, 1810-1820. doi: 10.1104/pp.107.111484

Harrison, M. J. (2005). Signaling in the arbuscular mycorrhizal symbiosis. Annu. Rev. Microbiol. 59, 19-42. doi: 10.1146/annurev.micro.58.030603.123749

Herman, M. A. B., Nault, B. A., and Smart, C. D. (2008). Effects of plant growthpromoting rhizobacteria on bell pepper production and green peach aphid infestations in New York. Crop Prot. 27, 996-1002. doi: 10.1016/j.cropro.2007. 12.004

Hermosa, R., Viterbo, A., Chet, I., and Monte, E. (2012). Plant-beneficial effects of Trichoderma and of its genes. Microbiology 158, 17-25. doi: 10.1099/mic.0. 052274-0 
Hong, G. J., Xue, X. Y., Mao, Y. B., Wang, L. J., and Chen, X. Y. (2012). Arabidopsis MYC2 interacts with DELLA proteins in regulating sesquiterpene synthase gene expression. Plant Cell 24, 2635-2648. doi: 10.1105/tpc.112. 098749

Hossain, M. T., Khan, A., Chung, E. J., Rashid, M. H., and Chung, Y. R. (2016). Biological control of rice bakanae by an endophytic Bacillus oryzicola YC7007. Plant Pathol. J. 32, 228-242. doi: 10.5423/PPJ.OA.10.2015.0218

Howe, G. A., and Jander, G. (2008). Plant immunity to insect herbivores. Annu. Rev. Plant Biol. 59, 41-66. doi: 10.1146/annurev.arplant.59.032607.092825

Jacobs, S., Zechmann, B., Molitor, A., Trujillo, M., Petutschnig, E., Lipka, V., et al. (2011). Broad-spectrum suppression of innate immunity is required for colonization of Arabidopsis roots by the fungus Piriformospora indica. Plant Physiol. 156, 726-740. doi: 10.1104/pp.111.176446

Johnson, M. T., Smith, S. D., and Rausher, M. D. (2009). Plant sex and the evolution of plant defenses against herbivores. Proc. Natl. Acad. Sci. U.S.A. 106, 18079-18084. doi: 10.1073/pnas.0904695106

Jones, J. D., and Dangl, J. L. (2006). The plant immune system. Nature 444, 323-329. doi: 10.1038 /nature05286

Ju, Y., Sacalis, J. N., and Still, C. C. (1998). Bioactive flavonoids from endophyteinfected blue grass (Poa ampla). J. Agric. Food Chem. 46, 3785-3788. doi: $10.1021 / \mathrm{j} f 980189 \mathrm{~m}$

Jung, S. C., Martinez-Medina, A., Lopez-Raez, J. A., and Pozo, M. J. (2012). Mycorrhiza-induced resistance and priming of plant defenses. J. Chem. Ecol. 38, 651-664. doi: 10.1007/s10886-012-0134-6

Kamolsukyunyong, W., Sukhaket, W., Ruanjaichon, V., Toojinda, T., and Vanavichit, A. (2013). Single-feature polymorphism mapping of isogenic rice lines identifies the influence of terpene synthase on brown planthopper feeding preferences. Rice 6, 18-26. doi: 10.1186/1939-8433-6-18

Kempel, A., Brandl, R., and Schädler, M. (2009). Symbiotic soil microorganisms as players in above ground plant-herbivore interactions-the role of rhizobia. Oikos 118, 634-640. doi: 10.1111/j.1600-0706.2009.17418.x

Kessler, A., Halitschke, R., and Baldwin, I. T. (2004). Silencing the jasmonate cascade: induced plant defenses and insect populations. Science 305, 665-668. doi: $10.1126 /$ science. 1096931

Kim, J. H., Lee, B. W., Schroeder, F. C., and Jander, G. (2008). Identification of indole glucosinolate breakdown products with antifeedant effects on Myzus persicae (green peach aphid). Plant J. 54, 1015-1026. doi: 10.1111/j.1365-313X. 2008.03476.x

Kiprovski, B., Malenčić, Đ, Đurić, S., Bursać, M., Cvejić, J., and Sikora, V. (2016). Isoflavone content and antioxidant activity of soybean inoculated with plantgrowth promoting rhizobacteria. J. Serb. Chem. Soc. 81, 1239-1249. doi: 10. 2298/JSC160422070K

Kloppholz, S., Kuhn, H., and Requena, N. (2011). A secreted fungal effector of Glomus intraradices promotes symbiotic biotrophy. Curr. Biol. 21, 1204-1209. doi: 10.1016/j.cub.2011.06.044

Koornneef, A., and Pieterse, C. M. (2008). Cross talk in defense signaling. Plant Physiol. 146, 839-844. doi: 10.1104/pp.107.112029

Kula, A. A., Hartnett, D. C., and Wilson, G. W. (2005). Effects of mycorrhizal symbiosis on tall grass prairie plant-herbivore interactions. Ecol. Lett. 8, 61-69. doi: $10.1111 / j .1461-0248.2004 .00690 . x$

Kusnierczyk, A., Winge, P., Jorstad, T. S., Troczynska, J., Rossiter, J. T., and Bones, A. M. (2008). Towards global understanding of plant defence against aphids timing and dynamics of early Arabidopsis defence responses to cabbage aphid (Brevicoryne brassicae) attack. Plant Cell Environ. 31, 1097-1115. doi: 10.1111/ j.1365-3040.2008.01823.x

Lakshmanan, V., Kitto, S. L., Caplan, J. L., Hsueh, Y. H., Kearns, D. B., Wu, Y. S., et al. (2012). Microbe-associated molecular patterns-triggered root responses mediate beneficial rhizobacterial recruitment in Arabidopsis. Plant Physiol. 160, 1642-1661. doi: 10.1104/pp.112.200386

Laluk, K., Luo, H., Chai, M., Dhawan, R., Lai, Z., and Mengiste, T. (2011). Biochemical and genetic requirements for function of the immune response regulator BOTRYTIS-INDUCED KINASE1 in plant growth, ethylene signaling, and PAMP-triggered immunity in Arabidopsis. Plant Cell 23, 2831-2849. doi: $10.1105 /$ tpc.111.087122

Lan, W., Lu, F., Regner, M., Zhu, Y., Rencoret, J., Ralph, S. A., et al. (2015). Tricin, a flavonoid monomer in monocot lignification. Plant Physiol. 167, 1284-1295. doi: $10.1104 /$ pp.114.253757
Lareen, A., Burton, F., and Schäfer, P. (2016). Plant root-microbe communication in shaping root microbiomes. Plant Mol. Biol. 90, 575-587. doi: 10.1007/ s11103-015-0417-8

Lei, J., Finlayson, S. A., Salzman, R. A., Shan, L., and Zhu-Salzman, K. (2014). BOTRYTIS-INDUCED KINASE1 modulates Arabidopsis resistance to green peach aphids via PHYTOALEXIN DEFICIENT4. Plant Physiol. 165, 1657-1670. doi: $10.1104 /$ pp.114.242206

Li, H., Soares, M. A., Torres, M. S., Bergen, M., and White, J. F. Jr. (2015). Endophytic bacterium, Bacillus amyloliquefaciens, enhances ornamental hosta resistance to diseases and insect pests. J. Plant Interact. 10, 224-229. doi: $10.1080 / 17429145.2015 .1056261$

Li, M., Pu, Y., Yoo, C. G., and Ragauskas, A. J. (2016). The occurrence of tricin and its derivatives in plants. Green Chem. 18, 1439-1454. doi: 10.1021/np2007796

Liu, X., Williams, C. E., Nemacheck, J. A., Wang, H., Subramanyam, S., Zheng, C., et al. (2010). Reactive oxygen species are involved in plant defense against a gall midge. Plant Physiol. 152, 985-999. doi: 10.1104/pp.109.150656

Lugtenberg, B., and Kamilova, F. (2009). Plant-growth-promoting rhizobacteria. Annu. Rev. Microbiol. 63, 541-556. doi: 10.1146/annurev.micro.62.081307. 162918

Maffei, M. E. (2010). Sites of synthesis, biochemistry and functional role of plant volatiles. S. Afr. J. Bot. 76, 612-631. doi: 10.1016/j.sajb.2010.03.003

Mao, Y. B., Cai, W. J., Wang, J. W., Hong, G. J., Tao, X. Y., Wang, L. J., et al. (2007). Silencing a cotton bollworm P450 monooxygenase gene by plant-mediated RNAi impairs larval tolerance of gossypol. Nat. Biotechnol. 25, 1307-1313. doi: $10.1038 /$ nbt1352

Martorana, L., Foti, M. C., Rondoni, G., Conti, E., Colazza, S., and Peri, E. (2017). An invasive insect herbivore disrupts plant volatile-mediated tritrophic signalling. J. Pest Sci. 90, 1079-1085. doi: 10.1007/s10340-017-0877-5

Mazid, M., Khan, T. A., and Mohammad, F. (2011). Role of secondary metabolites in defense mechanisms of plants. Biol. Med. 3, 232-249.

Mejía, L. C., Herre, E. A., Sparks, J. P., Winter, K., García, M. N., Van Bael, S. A., et al. (2014). Pervasive effects of a dominant foliar endophytic fungus on host genetic and phenotypic expression in a tropical tree. Front. Microbiol. 5:479. doi: $10.3389 /$ fmicb.2014.00479

Meldau, S., Erb, M., and Baldwin, I. T. (2012). Defence on demand: mechanisms behind optimal defence patterns. Ann. Bot. 110, 1503-1514. doi: 10.1093/aob/ $\operatorname{mcs} 212$

Mewis, I., Appel, H. M., Hom, A., Raina, R., and Schultz, J. C. (2005). Major signaling pathways modulate Arabidopsis glucosinolate accumulation and response to both phloem-feeding and chewing insects. Plant Physiol. 138, 1149-1162. doi: 10.1104/pp.104.053389

Mewis, I., Tokuhisa, J. G., Schultz, J. C., Appel, H. M., Ulrichs, C., and Gershenzon, J. (2006). Gene expression and glucosinolate accumulation in Arabidopsis thaliana in response to generalist and specialist herbivores of different feeding guilds and the role of defense signaling pathways. Phytochemistry 67, 2450-2462. doi: 10.1016/j.phytochem.2006.09.004

Millet, Y. A., Danna, C. H., Clay, N. K., Songnuan, W., Simon, M. D., WerckReichhart, D., et al. (2010). Innate immune responses activated in Arabidopsis roots by microbe-associated molecular patterns. Plant Cell 22, 973-990. doi: $10.1105 /$ tpc. 109.069658

Monaghan, J., and Zipfel, C. (2012). Plant pattern recognition receptor complexes at the plasma membrane. Curr. Opin. Plant Biol. 15, 349-357. doi: 10.1016/j.pbi. 2012.05.006

Müller, R., de Vos, M., Sun, J. Y., Sønderby, I. E., Halkier, B. A., Wittstock, U., et al. (2010). Differential effects of indole and aliphatic glucosinolates on lepidopteran herbivores. J. Chem. Ecol. 36, 905-913. doi: 10.1007/s10886-0109825-z

Mur, L. A., Kenton, P., Lloyd, A. J., Ougham, H., and Prats, E. (2007). The hypersensitive response; the centenary is upon us but how much do we know? J. Exp. Bot. 59, 501-520. doi: 10.1093/jxb/erm239

Nadeem, S. M., Zahir, Z. A., Naveed, M., and Arshad, M. (2007). Preliminary investigations on inducing salt tolerance in maize through inoculation with rhizobacteria containing ACC deaminase activity. Can. J. Microbiol. 53, 1141-1149. doi: 10.1139/W07-081

Niu, D. D., Liu, H. X., Jiang, C. H., Wang, Y. P., Wang, Q. Y., Jin, H. L., et al. (2011). The plant growth-promoting rhizobacterium Bacillus cereus AR156 induces systemic resistance in Arabidopsis thaliana by simultaneously activating 
salicylate-and jasmonate/ethylene-dependent signaling pathways. Mol. Plant Microbe Interact. 24, 533-542. doi: 10.1094/MPMI-09-10-0213

Pangesti, N., Pineda, A., Dicke, M., and Van Loon, J. J. A. (2015a). Variation in plant-mediated interactions between rhizobacteria and caterpillars: potential role of soil composition. Plant Biol. 17, 474-483. doi: 10.1111/plb.12265

Pangesti, N., Weldegergis, B. T., Langendorf, B., van Loon, J. J., Dicke, M., and Pineda, A. (2015b). Rhizobacterial colonization of roots modulates plant volatile emission and enhances the attraction of a parasitoid wasp to hostinfested plants. Oecologia 178, 1169-1180. doi: 10.1007/s00442-015-3277-7

Pangesti, N., Reichelt, M., van de Mortel, J. E., Kapsomenou, E., Gershenzon, J., van Loon, J. J., et al. (2016). Jasmonic acid and ethylene signaling pathways regulate glucosinolate levels in plants during rhizobacteria-induced systemic resistance against a leaf-chewing herbivore. J. Chem. Ecol. 42, 1212-1225. doi: $10.1007 / \mathrm{s} 10886-016-0787-7$

Paul, E. A. (2007). Soil Microbiology, Ecology, and Biochemistry. Cambridge, MA: Academic Press.

Pauwels, L., Inzé, D., and Goossens, A. (2009). Jasmonate-inducible gene: what does it mean? Trends Plant Sci. 14, 87-91. doi: 10.1016/j.tplants.2008.11.005

Pegadaraju, V., Knepper, C., Reese, J., and Shah, J. (2005). Premature leaf senescence modulated by the Arabidopsis PHYTOALEXIN DEFICIENT4 gene is associated with defense against the phloem-feeding green peach aphid. Plant Physiol. 139, 1927-1934. doi: 10.1104/pp.105.070433

Pieterse, C. M., Van der Does, D., Zamioudis, C., Leon-Reyes, A., and Van Wees, S. C. (2012). Hormonal modulation of plant immunity. Annu. Rev. Cell Dev. Biol. 28, 489-521. doi: 10.1146/annurev-cellbio-092910-154055

Pieterse, C. M., Van Wees, S. C., Van Pelt, J. A., Knoester, M., Laan, R., Gerrits, H., et al. (1998). A novel signaling pathway controlling induced systemic resistance in Arabidopsis. Plant Cell 10, 1571-1580. doi: 10.1105/tpc.10.9.1571

Pieterse, C. M., Zamioudis, C., Berendsen, R. L., Weller, D. M., Van Wees, S. C., and Bakker, P. A. (2014). Induced systemic resistance by beneficial microbes. Annu. Rev. Phytopathol. 52, 347-375. doi: 10.1146/annurev-phyto-082712- 102340

Pineda, A., Zheng, S. J., Van Loon, J. J. A., and Dicke, M. (2012). Rhizobacteria modify plant-aphid interactions: a case of induced systemic susceptibility. Plant Biol. 14, 83-90. doi: 10.1111/j.1438-8677.2011.00549.x

Pineda, A., Zheng, S. J., VanLoon, J. J. A., Pieterse, C. M. J., and Dicke, M. (2010). Helping plants to deal with insects: the role of beneficial soil-borne microbes. Trends Plant Sci. 15, 507-514. doi: 10.1016/j.tplants.2010.05.007

Pozo, M. J., Van Der Ent, S., Van Loon, L. C., and Pieterse, C. M. (2008). Transcription factor MYC2 is involved in priming for enhanced defense during rhizobacteria-induced systemic resistance in Arabidopsis thaliana. New Phytol. 180, 511-523. doi: 10.1111/j.1469-8137.2008.02578.x

Rahman, A., Uddin, W., and Wenner, N. G. (2015). Induced systemic resistance responses in perennial ryegrass against Magnaporthe oryzae elicited by semipurified surfactin lipopeptides and live cells of Bacillus amyloliquefaciens. Mol. Plant Pathol. 16, 546-558. doi: 10.1111/mpp.12209

Rani, P. U., and Jyothsna, Y. (2010). Biochemical and enzymatic changes in rice plants as a mechanism of defense. Acta Physiol. Plant 32, 695-701. doi: 10.1007/ s11738-009-0449-2

Rashid, M. H., Khan, A., Hossain, M. T., and Chung, Y. R. (2017). Induction of systemic resistance against aphids by endophytic Bacillus velezensis YC7010 via expressing PHYTOALEXIN DEFICIENT4 in Arabidopsis. Front. Plant Sci. 8:211. doi: 10.3389/fpls.2017.00211

Robert-Seilaniantz, A., Grant, M., and Jones, J. D. (2011). Hormone crosstalk in plant disease and defense: more than just jasmonate-salicylate antagonism. Annu. Rev. Phytopathol. 49, 317-343. doi: 10.1146/annurev-phyto-073009114447

Ryu, C. M., Farag, M. A., Hu, C. H., Reddy, M. S., Kloepper, J. W., and Paré, P. W. (2004). Bacterial volatiles induce systemic resistance in Arabidopsis. Plant Physiol. 134, 1017-1026. doi: 10.1104/pp.103.026583

Saravanakumar, D., Lavanya, N., Muthumeena, B., Raguchander, T., Suresh, S., and Samiyappan, R. (2008). Pseudomonas fluorescens enhances resistance and natural enemy population in rice plants against leaffolder pest. J. Appl. Entomol. 132, 469-479. doi: 10.1111/j.1439-0418.2008.01278.x

Saravanakumar, D., Muthumeena, K., Lavanya, N., Suresh, S., Rajendran, L., Raguchander, T., et al. (2007). Pseudomonas-induced defence molecules in rice plants against leaffolder (Cnaphalocrocis medinalis) pest. Pest Manag. Sci. 63, 714-721. doi: $10.1002 /$ ps.1381
Schausberger, P., Peneder, S., Juerschik, S., and Hoffmann, D. (2012). Mycorrhiza changes plant volatiles to attract spider mite enemies. Funct. Ecol. 26, 441-449. doi: 10.1111/j.1365-2435.2011.01947.x

Schoonhoven, L. M., Van Loon, J. J., and Dicke, M. (2005). Insect-Plant Biology. Oxford: Oxford University Press.

Segarra, G., Van der Ent, S., Trillas, I., and Pieterse, C. M. J. (2009). MYB72, a node of convergence in induced systemic resistance triggered by a fungal and a bacterial beneficial microbe. Plant Biol. 11, 90-96. doi: 10.1111/j.1438-8677. 2008.00162.x

Shah, J. (2005). Lipids, lipases, and lipid-modifying enzymes in plant disease resistance. Annu. Rev. Phytopathol. 43, 229-260. doi: 10.1146/annurev.phyto. 43.040204.135951

Shaharoona, B., Naveed, M., Arshad, M., and Zahir, Z. A. (2008). Fertilizerdependent efficiency of Pseudomonads for improving growth, yield, and nutrient use efficiency of wheat (Triticum aestivum L.). Appl. Microbiol. Biotechnol. 79, 147-155. doi: 10.1007/s00253-008-1419-0

Sharma, H. C., Sujana, G., and Rao, D. M. (2009). Morphological and chemical components of resistance to pod borer, Helicoverpa armigera in wild relatives of pigeonpea. Arthropod Plant Interact. 3, 151-161. doi: 10.1007/s11829-0099068-5

Shavit, R., Ofek-Lalzar, M., Burdman, S., and Morin, S. (2013). Inoculation of tomato plants with rhizobacteria enhances the performance of the phloemfeeding insect Bemisia tabaci. Front. Plant Sci. 4:306. doi: 10.3389/fpls.2013. 00306

Shoresh, M., Harman, G. E., and Mastouri, F. (2010). Induced systemic resistance and plant responses to fungal biocontrol agents. Annu. Rev. Phytopathol. 48, 21-43. doi: 10.1146/annurev-phyto-073009-114450

Singh, N., Yadav, A., and Varma, A. (2015). Effect of plant growth promoting activity of rhizobacteria on Cluster bean (Cyamopsis tetragonoloba L.) plant growth and biochemical constituents. Int. J. Curr. Microbiol. Appl. Sci. 4, 1071-1082.

Song, Y. Y., Ye, M., Li, C. Y., Wang, R. L., Wei, X. C., Luo, S. M., et al. (2013). Priming of anti-herbivore defense in tomato by arbuscular mycorrhizal fungus and involvement of the jasmonate pathway. J. Chem. Ecol. 39, 1036-1044. doi: 10.1007/s10886-013-0312-1

Spaink, H. P. (2000). Root nodulation and infection factors produced by rhizobial bacteria. Annu. Rev. Microbiol. 54, 257-288. doi: 10.1146/annurev.micro. 54.1.257

Steinkellner, S., Lendzemo, V., Langer, I., Schweiger, P., Khaosaad, T., Toussaint, J. P., et al. (2007). Flavonoids and strigolactones in root exudates as signals in symbiotic and pathogenic plant-fungus interactions. Molecules 12, 1290-1306. doi: $10.3390 / 12071290$

Stipanovic, R. D., Lopez, J. D. Jr., Dowd, M. K., Puckhaber, L. S., and Duke, S. E. (2006). Effect of racemic and (+)-and (-)-gossypol on the survival and development of Helicoverpa zea larvae. J. Chem. Ecol. 32, 959-968. doi: 10.1007/ s10886-006-9052-9

Syed, T. S., Abro, G. H., Khuhro, R. D., and Dhauroo, M. H. (2003). Relative resistance of cotton varieties against sucking pests. Pak. J. Biol. Sci. 6, 1232-1233. doi: 10.3923/pjbs.2003.1232.1233

Tong, X., Qi, J., Zhu, X., Mao, B., Zeng, L., Wang, B., et al. (2012). The rice hydroperoxide lyase OsHPL3 functions in defense responses by modulating the oxylipin pathway. Plant J. 71, 763-775. doi: 10.1111/j.1365-313X.2012. 05027.x

Vacheron, J., Desbrosses, G., Bouffaud, M. L., Touraine, B., Moënne-Loccoz, Y., Muller, D., et al. (2013). Plant growth-promoting rhizobacteria and root system functioning. Front. Plant Sci. 4:356. doi: 10.3389/fpls.2013.00356

Valenzuela-Soto, J. H., Estrada-Hernández, M. G., Ibarra-Laclette, E., and DélanoFrier, J. P. (2010). Inoculation of tomato plants (Solanum lycopersicum) with growth-promoting Bacillus subtilis retards whitefly Bemisia tabaci development. Planta 231, 397-410. doi: 10.1007/s00425-009-1061-9

van de Mortel, J. E., de Vos, R. C., Dekkers, E., Pineda, A., Guillod, L., Bouwmeester, K., et al. (2012). Metabolic and transcriptomic changes induced in Arabidopsis by the rhizobacterium Pseudomonas fluorescens SS101. Plant Physiol. 160, 2173-2188. doi: 10.1104/pp.112.207324

Van der Ent, S., Van Wees, S. C., and Pieterse, C. M. (2009). Jasmonate signaling in plant interactions with resistance-inducing beneficial microbes. Phytochemistry 70, 1581-1588. doi: 10.1016/j.phytochem.2009.06.009 
Van Loon, L. C. (2007). Plant responses to plant growth-promoting rhizobacteria. Eur. J. Plant Pathol. 119, 243-254. doi: 10.1007/s10658-007-9165-1

Van Oosten, V. R., Bodenhausen, N., Reymond, P., Van Pelt, J. A., Van Loon, L. C., Dicke, M., et al. (2008). Differential effectiveness of microbially induced resistance against herbivorous insects in Arabidopsis. Mol. Plant Microbe Interact. 21, 919-930. doi: 10.1094/MPMI-21-7-0919

Van Wees, S. C., Van der Ent, S., and Pieterse, C. M. (2008). Plant immune responses triggered by beneficial microbes. Curr. Opin. Plant Biol. 11, 443-448. doi: 10.1016/j.pbi.2008.05.005

Verhage, A., Vlaardingerbroek, I., Raaijmakers, C., Van Dam, N., Dicke, M., Van Wees, S., et al. (2011). Rewiring of the jasmonate signaling pathway in Arabidopsis during insect herbivory. Front. Plant Sci. 2:47. doi: 10.3389/fpls. 2011.00047

Verhagen, B. W., Glazebrook, J., Zhu, T., Chang, H. S., Van Loon, L. C., and Pieterse, C. M. (2004). The transcriptome of rhizobacteria-induced systemic resistance in Arabidopsis. Mol. Plant Microbe Interact. 17, 895-908. doi: 10.1094/MPMI.2004.17.8.895

Veronese, P., Nakagami, H., Bluhm, B., AbuQamar, S., Chen, X., Salmeron, J., et al. (2006). The membrane-anchored BOTRYTIS-INDUCED KINASE1 plays distinct roles in Arabidopsis resistance to necrotrophic and biotrophic pathogens. Plant Cell 18, 257-273. doi: 10.1105/tpc.105.035576

Walz, C., Juenger, M., Schad, M., and Kehr, J. (2002). Evidence for the presence and activity of a complete antioxidant defence system in mature sieve tubes. Plant $J$. 31, 189-197. doi: 10.1046/j.1365-313X.2002.01348.x

War, A. R., Paulraj, M. G., War, M. Y., and Ignacimuthu, S. (2011). Jasmonic acid-mediated-induced resistance in groundnut (Arachis hypogaea L.) against Helicoverpa armigera (Hubner) (Lepidoptera: Noctuidae). J. Plant Growth Regul. 30, 512-523. doi: 10.1007/s00344-011-9213-0

Wielkopolan, B., and Obrępalska-Stęplowska, A. (2016). Three-way interaction among plants, bacteria and coleopteran insects. Planta 244, 313-332. doi: 10.1007/s00425-016-2543-1

Wu, G., Guo, J. Y., Wan, F. H., and Xiao, N. W. (2010). Responses of three successive generations of beet armyworm, Spodoptera exigua, fed exclusively on different levels of gossypol in cotton leaves. J. Insect Sci. 10, 1-11. doi: $10.1673 / 031.010 .14125$

Yang, J. W., Yi, H. S., Kim, H., Lee, B., Lee, S., Ghim, S. Y., et al. (2011). Whitefly infestation of pepper plants elicits defence responses against bacterial pathogens in leaves and roots and changes the below-ground microflora. J. Ecol. 99, 46-56. doi: $10.1111 /$ j.1365-2745.2010.01756.x

Yi, H. S., Yang, J. W., Ghim, S. Y., and Ryu, C. M. (2011). A cry for help from leaf to root: Above ground insect feeding leads to the recruitment of rhizosphere microbes for plant self-protection against subsequent diverse attacks. Plant Signal. Behav. 6, 1192-1194. doi: 10.4161/psb.6.8.15780

Zahir, Z. A., Munir, A., Asghar, H. N., Shaharoona, B., and Arshad, M. (2008). Effectiveness of rhizobacteria containing ACC deaminase for growth promotion of peas (Pisum sativum) under drought conditions. J. Microbiol. Biotechnol. 18, 958-963.

Zamioudis, C., and Pieterse, C. M. (2012). Modulation of host immunity by beneficial microbes. Mol. Plant Microbe Interact. 25, 139-150. doi: 10.1094/ MPMI-06-11-0179

Zebelo, S., Song, Y., Kloepper, J. W., and Fadamiro, H. (2016). Rhizobacteria activates $(+)$ - $\delta$-cadinene synthase genes and induces systemic resistance in cotton against beet armyworm (Spodoptera exigua). Plant Cell Environ. 39, 935-943. doi: 10.1111/pce.12704

Zhang, H., Xie, X., Kim, M. S., Kornyeyev, D. A., Holaday, S., and Paré, P. W. (2008). Soil bacteria augment Arabidopsis photosynthesis by decreasing glucose sensing and abscisic acid levels in planta. Plant J. 56, 264-273. doi: 10.1111/j. 1365-313X.2008.03593.x

Zhang, P., Zhu, X., Huang, F., Liu, Y., Zhang, J., Lu, Y., et al. (2011). Suppression of jasmonic acid-dependent defense in cotton plant by the mealybug Phenacoccus solenopsis. PLOS ONE 6:e22378. doi: 10.1371/journal.pone.002 2378

Zheng, S. J., van Dijk, J. P., Bruinsma, M., and Dicke, M. (2007). Sensitivity and speed of induced defense of cabbage (Brassica oleracea L.): dynamics of BoLOX expression patterns during insect and pathogen attack. Mol. Plant Microbe Interact. 20, 1332-1345. doi: 10.1094/MPMI-20-111332

Zhou, G., Qi, J., Ren, N., Cheng, J., Erb, M., Mao, B., et al. (2009). Silencing OsHI-LOX makes rice more susceptible to chewing herbivores, but enhances resistance to a phloem feeder. Plant J. 60, 638-648. doi: 10.1111/j.1365-313X. 2009.03988.x

Conflict of Interest Statement: The authors declare that the research was conducted in the absence of any commercial or financial relationships that could be construed as a potential conflict of interest.

Copyright () 2017 Rashid and Chung. This is an open-access article distributed under the terms of the Creative Commons Attribution License (CC BY). The use, distribution or reproduction in other forums is permitted, provided the original author(s) or licensor are credited and that the original publication in this journal is cited, in accordance with accepted academic practice. No use, distribution or reproduction is permitted which does not comply with these terms. 